\title{
Proton exchange membrane fuel cell model for prognosis
}

\author{
A. H. Detti ${ }^{1,2}$, S. Jemei ${ }^{1,2}$, N. Yousfi Steiner ${ }^{1,2,3}$ \\ ${ }^{1}$ FEMTO-ST, CNRS, Univ. Bourgogne Franche-Comte, rue Thierry Mieg, F-90010 Belfort Cedex, France \\ ${ }^{2}$ FCLAB, CNRS, Univ. Bourgogne Franche-Comte, rue Thierry Mieg, F-90010 Belfort Cedex, France \\ ${ }^{3}$ Labex Action, CNRS, Besançon, France \\ \{abdelkader.detti, samir.jemei, nadia.steiner\}@femto-st.fr
}

\begin{abstract}
The deployment at a large-scale of fuel cells will only occur if it is sufficiently competitive with other conventional energy generation solutions. Indeed, it is essential that these new technologies can provide acceptable performance and guarantee continuity of service for users. This involves the deployment of a robust, fault tolerant and ageing resilient systems. Fuel cell systems, by their technology, have behaviors that are difficult to apprehend. The nonlinear nature of the phenomena, the reversible or non-reversible character of the degradations, and the interactions between components and parameters make the modeling of aging a difficult task [2]. It is however necessary to develop a complete ageing model of a Fuel Cell system depending on the operating conditions in order to extend the lifetime of the system by setting appropriate control. Fault and degradation tolerant control, or by setting predictive maintenance. In this work, we present a mathematical model that will be used for fuel cell system prognosis, part of a global fault resilient approach. The model developed has been validated on experimental tests.
\end{abstract}

Keywords-proton exchange membrane fuel cell; prognosis; fuel cell ageing, fuel cell model.

\section{INTRODUCTION}

In the context of regression of fossil energy sources and global warming, it is imperative to establish an energy transition. This transition involves the use of renewable energies. Hydrogen could be a very promising energy vector. Use hydrogen as an energy carrier and proton exchange membrane fuel cells to directly convert chemical energy into electrical energy, seems to be a promising alternative to fossil fuels for many applications such as stationary, portable and transportation.

Today, the automotive industry is mainly focused on the battery electric vehicles BEVs. However, this technology is not the only one to allow a clean mobility. Several manufacturers are also working on vehicles using an electric motor powered by a fuel cell, or a FC range extender to the BEVs.

A fuel cell is an electro-chemical device, which converts chemical energy from hydrogen to electrical energy. The proton exchange membrane fuel cell (PEMFC) consists of two electrodes (anode and cathode) separated by a polymeric membrane. Each electrode is composed of two layers: a catalytic layer and gas diffusion layer (GDL) Fig 1.

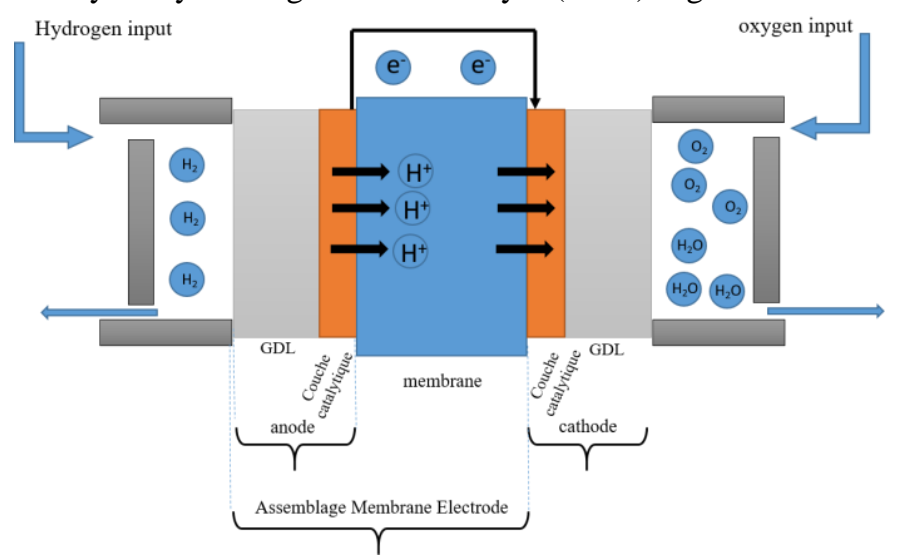

Fig 1. operating principle of a PEMFC

At the anode side, the reaction of reduction of the hydrogen takes place (Eq.1). In the presence of platinumbased catalyst, hydrogen is dissociated of its electrons according to the following equation:

$$
\mathrm{H}_{2} \rightarrow 2 \mathrm{H}^{+}+2 \mathrm{e}^{-}
$$

At the cathode side, ions $\mathrm{H}^{+}$, migrate through the membrane from the anode side. Electrons $\mathrm{e}^{-}$arrived from the electrical circuit. Oxygen is fed by the air circuit. The reaction between these chemical components produces water and heat, according to the following oxidation equation:

$$
\frac{1}{2} \mathrm{O}_{2}+2 \mathrm{H}^{+}+2 \mathrm{e}^{-} \rightarrow \mathrm{H}_{2} \mathrm{O}+\mathrm{Q} \text { (heat) }
$$

Which leads to the global reaction:

$$
\mathrm{H}_{2}+\frac{1}{2} \mathrm{O}_{2} \rightarrow \mathrm{H}_{2} \mathrm{O}+\mathrm{Q} \text { (heat) }
$$

This technology has many advantages including high efficiency, no mechanical moving parts and zero emissions [1]. This is why fuel cells have a good potential to gradually replace internal combustion engines in the future. [2,3] 
Among different fuel cell technologies, the proton exchange membrane fuel cell PEMFC seem to be the best candidate for embedded/ automotive applications. The stack composed of cells connected in series, fed with hydrogen and air produce a voltage less than $1 \mathrm{~V}$ per cell. The stack voltage varies from a few volts to a few hundred volts, depending on the number of cells connected.

To ensure a good operation of the fuel cell, it needs auxiliary components; in this case, a fuel cell system or Balance of Plant BoP has to be considered

The fuel cell system is, at least composed of six subsystems. Fig 1

The air supply subsystem is used to filter, heat, humidity and pressurize the air supplied to the stack.

Hydrogen supply subsystem supplies the stack with hydrogen and controls the flow.

Power management subsystem is required to establish the connection between the stack and the load to avoid transient current that could damage the fuel cell stack and controls the output voltage of the system to meet the needs of the application.

Thermal management subsystem: about half of the input chemical energy is converted into thermal energy, the thermal management subsystem uses this energy in the fuel cell system to preheat the fuel and air or provides thermal energy for Combined Heat Power (CHP) applications.

Water management subsystem uses water to humidify air and hydrogen.

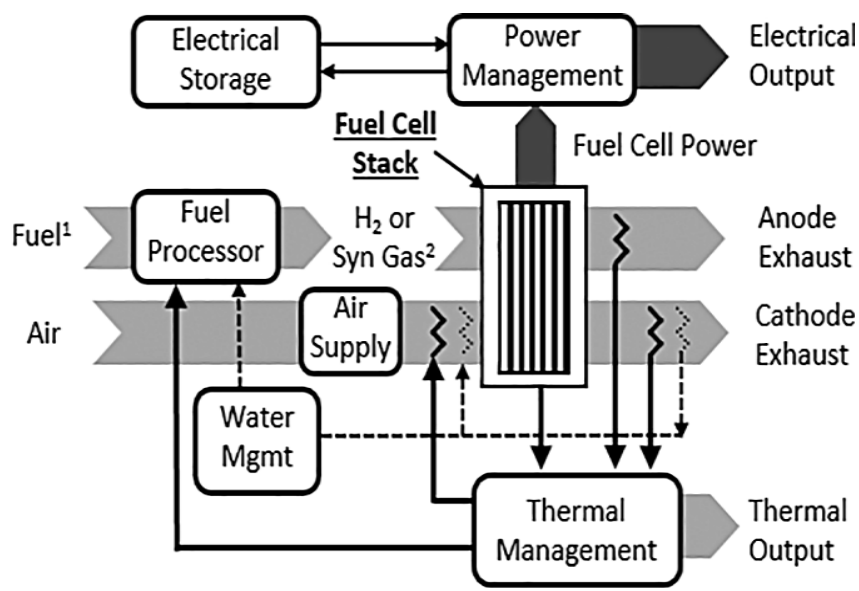

Fig 2. Fuel cell system [5]

Fuel cells are subject to several failures that reduce their life span and prevent their deployment at the industrial level. These mechanisms of degradation are irreversible and are not fully controlled. The degradation of the voltage due to these phenomena is difficult to predict because they depend on the operating conditions [4]. This is why the discipline of PHM (Prognosis and Health Management) of fuel cells is starting to develop. This allows monitoring, diagnosis, prognosis and help in making corrective decisions [5]. This discipline also makes it possible to build indicators of health status and trends, to plan preventive maintenance at the right time. By knowing the state of health and the remaining life of a multi- source system (eg fuel cell + batteries) it is easy to establish the energy management of the system, which allows to extend the life span and ensure the continuity of service of the system for a given mission.

The idea of this research work is to model the ageing of the components of the system. The experimental data coupled with the physical knowledge of the components will allow to establish a hybrid model of ageing for each element of the considered system. The second objective of this work is to model the ageing interactions between the system components.

The dynamics of ageing is rather slow compared to that of a defect that is rather quickly detectable. It is therefore important to develop existing fault propagation laws, which describe the behavior of the fuel cell system taking into account the influence of the ageing on the state of the system, and will be integrated in the overall ageing model.

The model developed will be the basis of a hybrid model of prognosis. The novelty will be, to use new degradation indicators identified from the static model, model their dynamics and use it to forecast and determine the remaining useful life. Define a prognosis taking into account the laws of propagation of defects in time. Indeed, in order to be closer to industrial developments a modular fuel cell system composed of several fuel cells is here considered. This paper is organized as follows:

A short review on fuel cell prognosis, degradation factors on PEMFC components, then the model of the hydrogen fuel cell stack is presented, and finally the validation results of the model, thanks to which we have been able to identify the internal parameters of the stack. The complete system model will be a perspective of this work.

\section{A SHORT REVIEW ON FUEL CELL PROGNOSIS}

There are several ageing models for PEMFCs in the literature. Among the first works about FC ageing, the work of Laffly et al. [6], where the authors proposed a static and dynamic model of a PEMFC based on an empirical equations and equivalent electrical impedance modeling. The parameters of the static and dynamic models are provided by the polarization curve (static characterization) and the electrochemical impedance spectroscopy (dynamic characterization). The study of the evolution of the parameters during the lifetime of the fuel cell makes it possible to understand the ageing of the stack. The results obtained show the ageing of the stack, through the increase of the membrane resistance, the increase of the cathode charge resistance and the decrease of the charges on the cathode / electrolyte.

Robin et al. [7] presented a global modeling approach that couples a multi-scale model that describes electrochemical degradations and cell-level material degradation mechanisms with a stack performance model, which can provide information about the system Fuel cell. Authors took into account the loss of platinum as a degradation mechanism and analyzed two modes of operation (optimal and power cycles).

Pathapati et al. [8] developed a dynamic model of a fuel cell thanks to Matlab software that takes into account transient 
dynamic mechanisms such as the double layer capacity, the dynamics of the gas flow, the pressure in the channels at both the anode and the cathode sides. The model can predict the transient response of voltage and cell temperature, the output rate of hydrogen and oxygen, the temperature and pressure at the channels of the anode and the cathode during a load current change. The prediction of the model has been validated on the basis of experimental tests.

In [9], the model is developed based on the identification of parameters using experimental PEMFC ageing data. This method uses a Kalman filter to estimate a degradation parameter that varies with the ageing time and represents the degradation of the stack and its derivative represents the degradation rate. The results obtained give an estimation of the state of health and the remaining useful life, which is an advantage for an embedded application.

In [10] the authors use two regression methods, to estimate the impedance of a PEMFC, and use it as a health indicator. The first method is a linear regression method that uses the least squares equations to predict impedances of the real part and the imaginary part, the second is a higher order polynomial regression combined with the function introduced by [44]. The results show that the linear regression method gives better results.

In another work, an approach to online prognosis is proposed [11]. The approach consists of introducing the discrete wavelet transform (DWT) and obtaining a set of approximation coefficients, then predictions are made on this set using the mathematical regression models: autoregressive integrated moving average (ARIMA) and polynomial regression. Authors estimate the error below $3 \%$.

Li et al. [12] proposed a new prognostic strategy for PEMFC under dynamic operating conditions. To reach this aim, a type of Linear Parameter Variation Model (LPV) is performed to model the dynamic process of the PEMFC system in a relatively short time. The prognosis is implemented using the Echo State Network (ESN) method. The method has been validated on $1500 \mathrm{~h}$ data tests.

Finally, another prognostic method developed in [13], used the particular filter. Authors use the adaptive parameter to adapt to the trend of degradation in the different ageing stages of PEMFCs. This method also takes into account the phenomena of recovery. The results predict the RUL with errors less than $5 \%$.

\section{FUEL CELL DEGRADATION}

Malfunctions in a fuel cell fall into two categories according to internal or external causes. Internal causes are due to the operation of the FC itself, such as irreversible damage due to ageing or the improper water management. The external causes are due to the pollutants brought by the gases in the Fuel Cell. The table 1 shows the factors affecting the components of a PEMFC.

In order to determine the state of health $(\mathrm{SOH})$ or the remaining useful life (RUL) of a PEMFC, degradation/ageing indicators are used. Several degradation indicators could be found in the literature: dissolution catalyst area dissolution
[15], rate of hydrogen that crosses over the membrane. Theses parameters give information that can physically explain the nature of the degradation and ageing. However, these parameters are not easily measured and their monitoring disturbs the PEMFC operation, and eventually accelerates the degradation and ageing [16]. The ageing and reversible degradations have a direct impact on the stack output voltage/power, which is a noninvasive parameter that is easy to monitor in a PEMFC. Morando et al. used mean cell voltage [17,18], stack voltage [19] and stack power as a degradation indicator [20].

Some solutions have been explored to overcome the problem of incapability to measure the internal parameters like EIS and other characterization methods.

Since these measurements give information about the ageing and the $\mathrm{SOH}$ of the fuel cell, it would be interesting to combine them with a physical model in a hybrid approach.

Table 1. degradation factors on PEMFC components

\begin{tabular}{|l|l|}
\hline Component & Degradation factors \\
\hline Catalyst layer & $\begin{array}{l}\text { Temperature, humidity, load } \\
\text { cycles, contaminants. }\end{array}$ \\
\hline Membrane & $\begin{array}{l}\text { Load cycles, rise in } \\
\text { temperature and low humidity, } \\
\text { temperature humidity, cycles, } \\
\text { pollutants, cations }\end{array}$ \\
\hline GDL & $\begin{array}{l}\text { High/subfreezing temperature, } \\
\text { Temperature, humidity, } \\
\text { cycling, high potential. }\end{array}$ \\
\hline Support Carbone & $\begin{array}{l}\text { High temperature, high water } \\
\text { content, environment rich in } \\
\text { oxygen, high potential. }\end{array}$ \\
\hline
\end{tabular}

The PEMFC is a complex multiphysics and multiscales system and the measurements are difficult to achieve, but we can take advantage of this complexity using new degradation indicators which correspond to the internal parameters of the stack. These indicators can provide information about the $\mathrm{SoH}$ of the PEMFC, provide a better understanding of the system behavior according to the operating conditions, and predict the remaining useful life, which in turn will allow developing new strategies to increase its lifespan.

\section{STATIC FUEL CELL MODEL}

The modeling of a PEMFC aims to reproduce its behavior and allows the definition of adequate conditions to extend the life of PEMFCs. The modeling takes into account the phenomena occurring during its operation (Nernst potential, activation losses, Ohmic losses and losses by concentration).

The vacuum potential of the cell is a function of the electrochemical potential of the oxidation-reduction reaction, under standard conditions of temperature and pressure (1atm, $25{ }^{\circ} \mathrm{C}$ ), is equal to $1.23 \mathrm{~V}$, in practice the no-load voltage is below $1 \mathrm{~V}$ [6]. The curve of polarization, also called VI curve, is the characteristic curve of the fuel cell. It represents the evolution of the voltage as a function of the current density.

$\mathrm{V}=\mathrm{En}-\eta_{\text {act }}-\eta_{\text {ohm }}-\eta_{\text {conc }}$ 
- $E_{n}$ represents the potential of Nernst.

- $\eta_{\text {act }}$ represents the activation losses.

- $\eta_{\text {ohm }}$ represents the ohmic losses.

- $\eta_{\text {conc }}$ represents the mass transport losses.

- Nernst potential

$\mathrm{E}_{\mathrm{n}}=-\frac{\Delta_{h}}{2 F}-\frac{R T}{2 F} \ln \left(P_{o 2}^{1 / 2} * P_{H 2}\right)$

$\Delta_{\mathrm{h}}$ : free enthalpy of formation $241,83 \times 103[\mathrm{~J}]$

$\mathrm{F}:$ constant of Faraday $=96485.3329[\mathrm{~A} . \mathrm{s} / \mathrm{mol}]$

$\mathrm{R}$ : perfect gaz constant 8,314

$\mathrm{T}:$ temperature $[\mathrm{K}]$.

$P_{\mathrm{O}_{2}}$ : oxygen partial pressure [bar].

$P_{H_{2}}$ : hydrogen partial pressure [bar].

- Activation losses

It corresponds to the energy that must be spent to cross the energy barrier of chemical reactions [14]. This barrier is due to the slowness of the electrochemical reaction on the surface of the electrodes [6]. Part of the voltage produced is lost during the chemical reaction that transfers the electrons to or from the electrode. They are represented by the following ButlerVolmer equation:

$\eta_{\text {act }}=\frac{R T}{2 \alpha F} \ln \left(\frac{j+j_{n}}{j_{0}}\right)$

$\alpha:$ load transfer coefficient

$\mathrm{j}:$ current density $\left[\mathrm{A} / \mathrm{cm}^{2}\right]$

$\mathrm{j}_{\mathrm{n}}$ : cross-over current density $\left[\mathrm{A} / \mathrm{cm}^{2}\right]$

$J_{0}:$ internal current density $\left[\mathrm{A} / \mathrm{cm}^{2}\right]$

- Ohmic losses

The current density increases with increasing fuel flow, but the electrical resistance of the electrodes and the flow resistance of the membrane ions cause a voltage drop. These losses are defined by the equation below

$$
\eta_{\text {ohm }}=\mathrm{j} \times \mathrm{R}_{\text {int }}
$$

$\mathrm{R}_{\mathrm{int}}=\frac{r_{m \times l}}{A}$

$\mathrm{R}_{\text {int }}$ internal resistance $[\Omega]$

1 : membrane thickness.

$r_{m}:$ membrane resistivity [ $\left.\Omega . \mathrm{cm}\right]$

\section{- Mass transport losses}

Transport losses, also known as concentration losses, are due to the inability to carry enough reactants at high current density, which causes a drop in their concentrations at the surface of the electrodes. They are modeled by the following equation

$\eta_{\mathrm{conc}}=\frac{R T}{2 F} \ln \left(1-\frac{j}{j_{l}}\right)$

$I_{l}$ : current density limit $\left[\mathrm{A} / \mathrm{cm}^{2}\right]$.

$\mathrm{j}$ : current density $\left[\mathrm{A} / \mathrm{cm}^{2}\right]$.

\section{RESULTS}

A fuel cell can be characterized by its polarization curve.

The model is simulated thanks to Matlab Software under operating conditions represented in table 1 :

Table 2. model parameters

\begin{tabular}{|l|l|l|l|l|l|l|l|l|l|}
\hline $\mathrm{P}_{\mathrm{O} 2}$ & $\mathrm{P}_{\mathrm{H} 2}$ & $\mathrm{~T}$ & $\begin{array}{l}\text { Nbr } \\
\text { of } \\
\text { cell }\end{array}$ & $\begin{array}{l}\text { Active } \\
\text { area }\end{array}$ & $\alpha$ & $\mathrm{J}_{\mathrm{n}}$ & $\mathrm{J}_{0}$ & $\mathrm{~J}_{1}$ & $\mathrm{r}$ \\
\hline $\begin{array}{l}1,5 \\
{[\mathrm{bar}]}\end{array}$ & $\begin{array}{l}1,5 \\
{[\mathrm{bar}]}\end{array}$ & $\begin{array}{l}80 \\
{\left[{ }^{\circ} \mathrm{C}\right]}\end{array}$ & 20 & $\begin{array}{l}100 \\
{\left[\mathrm{~cm}^{2}\right]}\end{array}$ & 0.34 & $\begin{array}{l}2,5 \mathrm{e}-3 \\
{\left[\mathrm{~A} / \mathrm{cm}^{2}\right]}\end{array}$ & $\begin{array}{l}5,8^{\mathrm{e}-3} \\
{\left[\mathrm{~A} / \mathrm{cm}^{2}\right]}\end{array}$ & $\begin{array}{l}0.83 \\
{\left[\mathrm{~A} / \mathrm{cm}^{2}\right]}\end{array}$ & $\begin{array}{l}10,95^{\mathrm{e}-2} \\
{\left[\Omega . \mathrm{cm}^{2}\right]}\end{array}$ \\
\hline
\end{tabular}

The model gives the results shown in fig. 2 where the polarization curve and the different transient phenomena are presented.

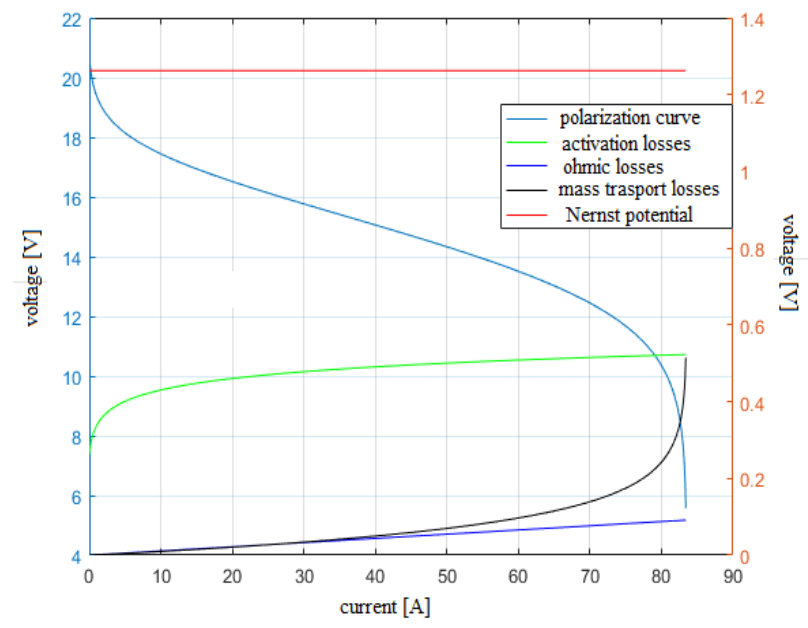

Fig3. Polarization curve and different losses.

Tests were carried out on a $3 \mathrm{M}$ fuel cell. This one is composed of 30 cells with an active surface area of $100 \mathrm{~cm}^{2}$. The tests are intended to diagnose problems related to water management. The model validation was done on the normal operating conditions Fig (3).

Table 3. operating conditions

\begin{tabular}{|c|c|c|c|c|c|}
\hline Test $\mathrm{n}^{\circ}$ & $\begin{array}{c}\mathrm{HR}_{\mathrm{a}} \\
{[\%]}\end{array}$ & $\mathrm{HR}_{\mathrm{c}}[\%]$ & $\mathrm{S}_{\mathrm{a}}[]$ & $\mathrm{S}_{\mathrm{c}}[]$ & $\mathrm{T}\left[\mathrm{C}^{\circ}\right]$ \\
\hline 6 & 35 & 75 & 1.8 & 3 & 80 \\
\hline
\end{tabular}

Thanks to the experimental polarization curve, it was possible to define, using the model, the internal parameters of 
the stack. They were used to reconstruct the polarization curve and validate the model.

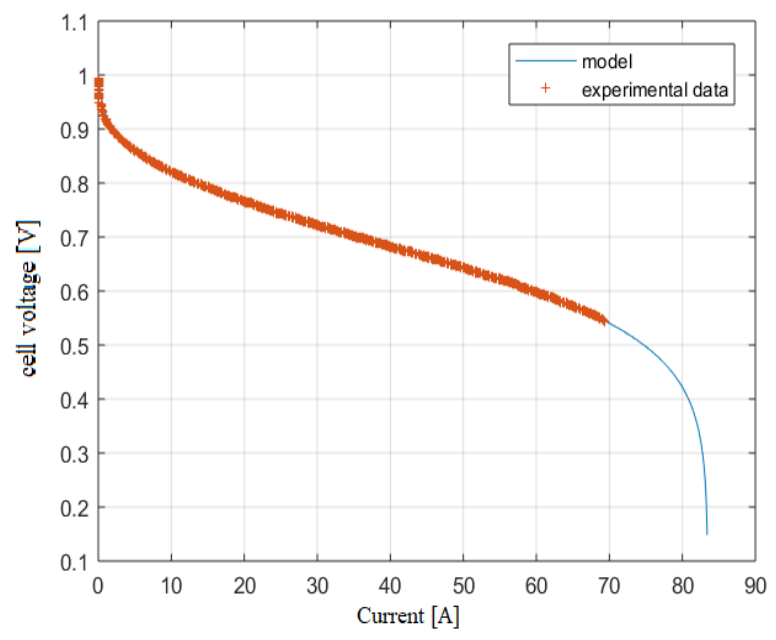

Fig 4. Validation on experimental data.

The stack ageing causes the variation of its internal parameters: load transfer coefficient, internal current density, cross-over current density and current limit density.

The load transfer coefficient takes place in the activation losses. It indicates the state of the used catalyst. During the ageing of the stack, the catalytic surface decreases and therefore this effect will be visible on the load transfer coefficient.

In practice, in a fuel cell, some fuel will diffuse from the anode to the cathode through the electrolyte. Because of the catalyst, it will directly react with oxygen, producing no current from the cell. This amount of wasted fuel that migrates through the electrolyte is known as the crossover current. This latter impacts activation losses and is related to proton resistance. [9]

Internal current is essentially equivalent to crossover current. During the crossing of one molecule of hydrogen from anode to the cathode where it reacts, two electrons are wasted which cross from anode to cathode internally. This later impacts the overvoltage losses.

The current density produced cannot exceed the limiting current density because the fuel gas cannot be provided faster. The limiting current density is a current at which the fuel is used up at a rate equal to its maximum supply speed. This current density gives information about catalytic surface and affects the mass transport losses.

The ohmic losses are affected only by the resistance of the electrodes and the resistance to the flow of ions in the electrolyte. In most fuel cells, the resistance is mainly caused by the electrolyte. The resistance is a good indicator of ageing of the stack.

In future works, long-term ageing tests under a constant load profile, will be conducted in order to study the variation of the internal parameters.
These internal parameters will be identified by fitting the experimental polarization curves and the model curve, thanks to an optimization method "genetic algorithm"

An Auto Regressive Moving Average (ARMA) model will be used to model their evolution over time. Use these ARMA models to predict the evolution of the internal parameters, and in a final step, reconstruct the polarization (fig.5) curves from the prediction results using the static model presented above. After that, it will be easy to define the remaining useful life (RUL) of the stack.

The coupling of the static model and experimental data, involves a hybrid prognosis method. This method allows, at first, to better understand the internal physical phenomena and better explain the ageing effects, and then to have more accurate results thanks to a large database.

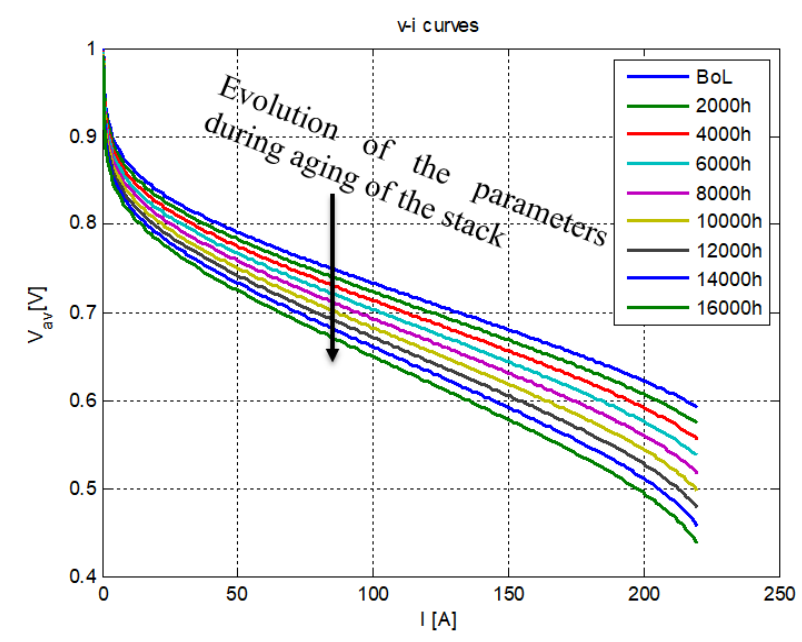

Fig 5. methodology of the approach that will be used

\section{CONCLUSION}

The developed model allowed us to study the performance of the fuel cell. The model is validated on experimental data. In the final paper, the study will be done on the evolution of the internal parameters of the stack, that will be determined using long term aging data, followed by a complete model of the system, including ageing.

\section{ACKNOWLEDGEMENT}

The authors gratefully acknowledge the ANR DIAPASON project and the LABEX-ACTION (ANR-11-LABX-01-01), which funds enabled the realization of this work and the corresponding experimental campaigns.

\section{References}

[1] R.E. Silva, Rafael Gouriveau, Samir Jemei, Daniel Hissel, Loïc Boulon, et al.. Proton exchange membrane fuel cell degradation prediction based on Adaptive Neuro-Fuzzy Inference Systems .. International Journal of Hydrogen Energy, Elsevier, 2014, 39, pp.11128-11144J. Clerk Maxwell, A Treatise on Electricity and Magnetism, 3rd ed., vol. 2. Oxford: Clarendon, 1892, pp.68-73.

[2] ISchäfer A, Heywood JB, Weiss MA. Future fuel cell and internal combustion 
[3] Calhau K, Gonçalves G, Farias T. Environmental impact of hydrogen in urban

[4] M. Jouin, R. Gouriveau, D. Hissel, M. C. P'era, and N. Zerhouni, "PEMFC aging modeling for prognostics and health assessment," IFACPapersOnLine, vol. 48, no. 21, pp. 790-795, 2015Development, Evora, Portugal, 28 June-1 July 2004; 2007:285.

[5] Jouin M, Gouriveau R, Hissel D, Pera M, Zerhouni N. Prognostics of PEM fuel cell in a particle filtering framework. Int J Hydrogen Energy 2014;39:481-94.

[6] Elie Laffly, Marie-C'ecile P'era, Daniel Hissel, Polymer Electrolyte Membrane Fuel Cell Modelling and Parameters Estimation for Ageing Consideration, IEEE 2007.

[7] Christophe Robin, Mathias Gerard*, Alejandro A. Franco, Pascal Schott, Multi-scale coupling between two dynamical models for PEMFC aging prediction, international journal of hydrogen energy 2012.

[8] Pathapati P, Xue X, Tang J. "A new dynamic model for predicting transient phenomena in a pem fuel cell system". Renew Energy 2005;30(1):1-22.

[9] A. Docter and A. Lamm, Fuel Cell Systems Explained. John Wiley Sons Ltd, UK, 2003

[10] W. O. L. Vianna, I. P. de Medeiros, B. S. Aflalo, L. R. Rodrigues, and J. P. P. Malre, "Proton Exchange Membrane fuel cells (PEMFC) impedance estimation using regression analysis," in IEEE Conference on Prognostics and Health Management, 2014, pp. 1-8.

[11] Mona Ibrahim, Nadia Yousfi Steiner, Samir Jemei, and Daniel Hissel, "Wavelet-Based Approach for Online Fuel Cell Remaining Useful Lifetime Prediction" IEEE TRANSACTIONS ON INDUSTRIAL ELECTRONICS, VOL. 63, NO. 8, AUGUST 2016

[12] Zhongliang Li, Samir Jeme"1, Rafael Gouriveau, Daniel Hissel, Noureddine Zerhouni, "Remaining useful life estimation for PEMFC in dynamic operating conditions“, IEEE 2016.
[13] J. K. Kimotho, T. Meyer, and W. Sextro, "PEM fuel cell prognostics using particle filter with model parameter adaptation," in IEEE Conference on Prognostics and Health Management, 2014 pp. 1-6.

[14] Mathieu Le Ny. Diagnostic non invasif de piles à combustible par mesure du champ magnétique proche. Energie électrique. Université de Grenoble, 2012.

[15] Christophe Robin, Mathias Gerard*, Alejandro A. Franco, Pascal Schott, Multi-scale coupling between two dynamical models for PEMFC aging prediction, international journal of hydrogen energy 2012.

[16] Dacheng Zhang. Contribution to prognostics of PEM fuel cells: approaches based on degradation information at multiple levels. Automatic. Communauté Université Grenoble Alpes, 2018. English. $<$ tel-01725849>

[17] S. Morando, S. Jemei, D. Hissel, R. Gouriveau, and N. Zerhouni, "ANOVA method applied to Proton Exchange Membrane fuel cell ageing forecasting using an echo state network," Mathematics and Computers in Simulation, pp. 1-12, 2015.

[18] S. Morando, S. Jemei, R. Gouriveau, N. Zerhouni, and D. Hissel, "Fuel cells prognostics using echo state network," in IEEE Conference on Industrial Electronics Society, 2013, pp. 1632-1637

[19] M. Bressel, M. Hilairet, D. Hissel, and S. Member, "Remaining Useful Life Prediction and Uncertainty Quantification of Proton Exchange Membrane Fuel Cell Under Variable Load," vol. 0046, no. c, 2016.

[20] M. Jouin, R. Gouriveau, D. Hissel, M. C. P'era, and N. Zerhouni "Degradations analysis and aging modeling for health assessment and prognostics of PEMFC," Reliability Engineering and System Safety, vol. 148, pp. 78-95, 2016 